\title{
Pengaru Pendekatan Saintifik Berbantuan Talking Stick Terhadap Keterampilan Membaca
}

\author{
Gusti Ayu Istya Utami ${ }^{*}$, I. Ketut. Dibia ${ }^{2}$, Putu. Aditya Antara ${ }^{3}$ \\ ${ }_{12}$ Prodi Pendidikan Guru Sekolah Dasar, Universitas Pendidikan Ganesha, Indonesia \\ ${ }^{3}$ Prodi Pendidikan Guru Pendidikan Anak Usia Dini, Universitas Pendidikan Ganesha Indonesia
}

\author{
A R T I C LE INFO \\ Article history: \\ Received 18 Desember \\ 2019 \\ Received in revised form \\ 30 Desember 2019 \\ Accepted 15 Januari 2020 \\ Available online 20 \\ Februari 2020 \\ Kata Kunci: \\ pendekatan saintifik, \\ keterampilan membac \\ Keywords \\ scientific approach, reading \\ comprehension
}

\begin{abstract}
A B S T R A K
Penelitian ini bertujuan untuk mengetahui pengaruh pendekatan saintifik berbantuan talking stick terhadap keterampilan membaca pemahaman kelas IV SD di Gugus IV Kecamatan Tejakula Kabupaten Buleleng tahun pelajaran 2018/2019. Populasi penelitian ini adalah kelas IV di Gugus IV Kecamatan Tejakula Kabupaten Buleleng tahun pelajaran 2018/2019 yang berjumlah 195 orang. Sampel penelitian ini adalah kelas IV di SD Negeri 3 Bondalem yang berjumlah 23 orang dan kelas IV SD Negeri 5 Bondalem yang berjumlah 22 orang. Instrumen pengumpulan data yang digunakan berupa tes berbentuk pilihan ganda dengan jumlah soal sebanyak 25 soal. Data yang dikumpulkan dianalisis menggunakan analisis statistik deskriptif dan statistik inferensial (uji-t). Berdasarkan hasil analisis, diperoleh thit sebesar 5,68 lebih dari tab sebesar 2,007 yang diuji pada taraf signifikansi 5\% dengan derajat kebebasan 43. Proses pembelajaran hendaknya lebih mengkreasikan pembelajaran dengan menerapkan model-model pembelajaran yang inovatif, salah satunya adalah penerapan pendekatan saintifik agar dapat meningkatkan keterampilan membaca siswa, sebab telah terbukti pada penelitian ini bahwa terdapat perbedaan yang signifikan terhadap keterampilan membaca pemahaman antara kelompok eksperimen dan kelompok kontrol. Berdasarkan hal
\end{abstract} tersebut pendekatan saintifik berbantuan talking stick berpengaruh terhadap keterampilan membaca pemahaman siswa kelas IV di Gugus IV Kecamatan Tejakula Kabupaten Buleleng Tahun Pelajaran 2018/2019.

\section{A B S T R A C T}

This study aimed to find out the effect of the scientific approach assisted with talking sticks on reading comprehension skills of fourth frade elementary school at SD di Gugus IV Kecamatan Tejakula Kabupaten Buleleng in 2018/2019 academic year. The population of this study was fourth grade students at SD di Gugus IV Kecamatan Tejakula Kabupaten Buleleng in 2018/2019 academic year which consist of 195 students. The sample of this study was fourth grade students at SD Negeri 3 Bondalem which consisted of 23 students and fourth grade students at SD Negeri 5 Bondalem which consisted of 22 students. The Instrument was in the form of a multiple-choice test with 25 questions. The data collected were analyzed by using descriptive statistics analysis and inferential statistics ( $t$-test). Based on the results of the analysis, it was found that $t_{o b s}$ (5.68) was higher than table (2.007) at 5\% significance and 43 degrees of freedom. The learning process should be more creative by applying innovative learning models, one example was the application of a scientific approach in order to improve students' reading comprehension. It has been proven in this study that there was a significant difference in reading comprehension skills between the experimental group and the control group. Based on this, the scientific approach assisted with talking stick approach influences reading comprehension skills of fourth grade students at SD di Gugus IV Kecamatan Tejakula Kabupaten Buleleng in 2018/2019 academic year.

Copyright (C) Universitas Pendidikan Ganesha. All rights reserved.

\section{Pendahuluan}

Pembelajaran Bahasa Indonesia diarahkan untuk meningkatkan kemampuan peserta didik agar mampu berkomunikasi dengan baik dan benar serta melatih keterampilan berpikir kritis dan kreatif. (Susanto, 2013:246) menyatakan bahwa Bahasa Indonesia merupakan suatu alat yang penting dalam rangka merealisasikan dalam mencapai tujuan kebahasaan Indonesia yang dipelajari oleh semua siswa dari sekolah dasar hingga sekolah menengah atas bahkan di perguruan tinggi. Pembelajaran bahasa Indonesia memiliki peran yang sangat penting bukan hanya untuk membina keterampilan komunikasi melainkan juga untuk kepentingan penguasaan ilmu pengetahuan. Melalui bahasa manusia belajar berbagai macam pengetahuan yang ada di dunia, oleh karenanya wajarlah jika para filsuf menganggap

1 Corresponding author.

E-mail addresses: gstayuistyautami@gmail.com¹(Istya), iketut.dibia@undiksha.ac.id²(Dibia),

putuaditya.antara@undiksha.ac.id³(Aditya) 
bahawa bahasa merupakan induk ilmu pengetauan di samping matematika. (Dibia, 2007:1) menyatakan "pembelajaran Bahasa Indonesia tidak akan terlepas dari empat keterampilan berbahasa yaitu menyimak, berbicara, membaca dan menulis". Keempat keterampilan bahasa tersebut sangat penting dan wajib dimiliki oleh peserta didik sebagai sarana atau modal awal untuk berinteraksi dengan orang lain. Agar siswa dapat menggunakan bahasa dalam suatu interaksi, maka ia harus memiliki keterampilan yaitu keterampilan berbahasa. Keterampilan tersebut digunakan untuk mengomunikasikan pesan. Pesan ini dapat berupa ide, keinginan kemauan, perasaan ataupun interaksi. Salah satu cara yang dapat digunakan untuk berinteraksi adalah melalui mebaca.

Membaca menjadi sebuah aktivitas yang dapat dilakukan oleh semua orang baik siswa maupun masyarakat umum. Keterampilan membaca yang memadai wajib dimiiliki oleh pembaca, karena kemampuan membaca yang memadai akan memudahkan pembaca untuk memahami isi bacaan. Tarigan (dalam Saddhono \& Slamet, 2014:100) menyatakan bahwa keterampilan membaca pemahaman adalah suatu proses yang dilakukan serta dipergunakan oleh pembaca tingkat lanjut untuk memperoleh makna pesan yang hendak disampaikan oleh penulis melalui media kata-kata dan bahasa tulis.

Melalui membaca pemahaman seseorang akan memperoleh makna dari suatu informasi, ilmu pengetahuan serta pengalaman-pengalaman baru. Ketika pembaca sudah dapat memahami isi bacaan yang dibacanya, keinginan penulis untuk memberikan informasi kepada pembaca melalui bacaan dapat dikatakan sudah berhasil. Ketika melakukan kegiatan membaca untuk mendapatkan pemahaman, masih banyak siswa yang hanya sekedar membaca namun setelah membaca, siswa tidak memahami isi dari bacaan tersebut. Karena kebiasaan itulah, maka ketika diberikan evaluasi berhubungan dengan materi bacaan tersebut untuk menilai kemampuan pemahaman mereka, hasil belajar keterampilan membaca pemahaman siswa tersebut tidak memuaskan.

Sebelumnya telah dilakukan wawancara pada bulan Januari 2019 terhadap guru kelas IV SD di gugus IV Kecamatan Tejakula. Berdasarkan hasil wawancara yang dilakukan dengan guru, diperoleh informasi bahwa keterampilan membaca siswa masih rendah. Pernyataan tersebut didukung oleh pencatatan dokumen yang sudah diperoleh. Pencatatan dokumen tersebut berupa nilai rata-rata hasil UAS keterampilan membaca siswa kelas IV tahun pelajaran 2018/1019. Nilai tersebut dijabarkan pada tabel 1.

Tabel 01 Rata-rata Nilai UAS Siswa Kelas IV SD di Gugus IV Kecamatan Tejakula Keterampilan Membaca

\begin{tabular}{ccccc}
\hline No. & Sekolah & Jumlah Siswa & KKM & Rata-rata \\
\hline 1 & SD N 1 Bondalem & 34 & 70 & 61,03 \\
2 & SD N 2 Bondalem & 11 & 65 & 62,32 \\
3 & SD N 3 Bondalem & 23 & 70 & 60,99 \\
4 & SD N 4 Bondalem & 20 & 70 & 63,76 \\
4 & SD N 5 Bondalem & 22 & 65 & 62,21 \\
6 & SD N 6 Bondalem & 28 & 70 & 61,77 \\
7 & SD N 7 Bondalem & 18 & 65 & 60,32 \\
8 & SD N 8 Bondalem & 14 & 70 & 62,08 \\
9 & SD N 9 Bondalem & 25 & 65 & 63,25 \\
\hline
\end{tabular}

(Sumber: wali kelas IV SD Gugus IV Kecamatan Tejakula)

Berdasarkan data pada tabel 1, diketahui terdapat kesenjangan antara harapan dan kenyataan pada muatan pelajaran Bahasa Indonesia khususnya keterampilan membaca. Hasil pada tabel 1 terlihat bahwa keberhasilan pencapaian nilai keterampilan membaca pada muatan pelajaran Bahasa Indonesia kelas IV SD Gugu IV Kecamatan Tejakula tergolong rendah dan belum mencapai hasil belajar yang memuaskan. Hal ini dapat terlihat pada tabel di atas menunjukkan nilai rata-rata keterampilan menulis siswa yang masih di bawah KKM. Berdasarkan hasil wawancara yang dilakukan dengan guru kelas IV SD Gugus IV Kecamatan Tejakula pada bulan Januari 2019, didapatkan hasil bahwa guru mengatakan mengalami kesulitan dalam pembelajaran membaca. Kesulitan-kesulitan yang dihadapi oleh guru adalah cara membuat siswa tertarik untuk mengikuti pelajaran membaca, kurangnya pemahaman dalam 
menggunakan media atau model pembelajaran serta keterlibatan siswa dalam proses pembelajaran masih kurang.

Hal itu didukung dengan hasil observasi yang dilakukan di kelas selama pembelajaran membaca. Hasilnya, ditemukan hal-hal sebagai berikut. 1) guru tidak menggunakan media maupun model pembelajaran, 2) siswa tampak tidak tertarik mengikuti pembelajaran membaca. Hal ini terlihat dari kegiatan yang dilakukan siswa selama pembelajaran yaitu siswa tidak mendengarkan penjelasan dari guru dan siswa berbicara dengan temannya tentang hal-hal di luar pembelajaran. 3) siswa kesulitan dalam menentukan ide topik yang akan dibaca. Hal ini terlihat dari beberapa siswa bertanya kepada temanya mengenai judul/topik yang digunakan, kemudian siswa tersebut mengikuti judul/topik yang digunakan oleh temannya. 4) setelah mendapatkan ide, siswa kebingungan dan kurang percaya diri dalam membacakan/menyampaikan ide yang telah didapat. Berdasarkan hasil yang telah diperoleh saat observasi, dapat disimpulkan bahwa pembelajaran yang dilakukan oleh guru tidak menarik minat siswa untuk belajar sehingga siswa menjadi kurang aktif dalam pembelajaran membaca.

Berdasarkan permasalahan yang ditemukan, perlu diadakan pembelajaran yang dapat membuat siswa aktif dan senang belajar membaca. Guna memenuhi hal tersebut, pembelajaran yang dipilih dan sesuai untuk mengatasi masalah yang terjadi adalah pembelajaran yang difokuskan menarik minat siswa dalam mengikuti pelajaran membaca. Salah satu yang harus di lakukan yaitu Pendekatan saintifik berbantuan talking stick. Pelaksanaan pembelajaran berdasarkan kurikulum 2013 yaitu menggunakan pendekatan saintifik atau pendekatan berbasis keilmuan. Musfigon dan Nurdyansyah (2015:57) menyatakan penerapan pendekatan saintifik (ilmiah) dalam pembelajaran di sekolah bertujuan membiasakan peserta didik berpikir, bersikap, serta berkarya dengan menggunakan kaidah dan langkah ilmiah. Pendekata saintifik meliputi lima pengalaman belajar yaitu mengamati, menanya, mencoba, menalar, dan mengasosiasikan. Kelima langkah ini sesuai diterapkan pada pembelajaran membaca karena dapat melatih siswa dalam kegiatan membaca dari mencari ide, mengolah ide sampai menyampaikan ide tersebut. Hal ini akan membuat siswa memiliki kemampuan membaca yang baik.

Selain pendekatan saintifik, untuk menambah pemahaman siswa dalam membaca, dapat dibantu dengan penggunaan metode yang tepat yaitu metode talking stick. Menurut (Kurniasih, 2016:82) model pembelajaran talking stick merupakan satu dari sekian banyak model pembelajaran kooperatif. Model pembelajaran ini dilakukan dengan bantuan tongkat. Tongkat dijadikan sebagai jatah atau giliran untuk berpendapat atau menjawab pertanyaan dari guru. Model ini sangat sederhana dan mudah diperaktekkan, selain sebagai metode agar siswa mau untuk membaca dan berpendapat model pembelajaran ini juga dapat membuat suasana kelas terlihat lebih hidup dan tidak monoton. Penggunaan model pembelajaran talking stick ini akan dipadukan dalam pendekatan saintifik sehingga pembelajaran membaca yang dilakukan siswa menjadi lebih bermakna dan menyenangkan.

Berkaitan dengan hasil belajar keterampilan membaca pemahaman, pendekatan saintifik berbantuan talking stick siswa diharapkan menjadi lebih aktif dalam proses pembelajaran dan merasakan pembelajaran yang menyenangkan. Siswa akan memiliki motivasi yang besar dalam pembelajaran karena pembelajaran di dominasi dengan permainan sehingga diharapkan hasil belajarnya menjadi lebih meningkat.

Berdasarkan berbagai pemaparan di atas, penelitian ini bertujuan untuk mengetahui apakah terdapat pengaruh keterampilan membaca pemahaman siswa yang dibelajarkan dengan pendekatan Saintifik berorientasi Talking Stick dari pada yang dibelajarkan dengan model konvesnsional terhadap Keterampilan membaca pemahaman Siswa Kelas IV SD Gugus IV Kecamatan Tejakula Kabupaten Buleleng Tahun 2018/2019.

\section{Metode}

Jenis penelitian yang dilakukan adalah penelitian eksperimen. Penelitian eksperimen merupakan penelitian yang digunakan untuk mengetahui pengaruh dari suatu tindakan atau perlakuan tertentu yang sengaja dilakukan terhadap suatu kondisi tertentu. Pada penelitian ini, penelitian eksperimen yang dilakukan adalah eksperimen semu (quasi eksperiment). Dalam eksperimen mempunyai kelompok kontrol, tetapi tidak berfungsi sepenuhnya untuk mengontrol variable-variabel luar yang mempengaruhi pelaksanaan eksperimen. Desain eksperimen yang digunakan adalah eksperimen semu (quasi eksperiment). Desain ini dipilih karena tidak memungkin mengubah kelas yang ada. Desain eksperimen semu yang digunakan dalam hal ini adalah "Post Test Only Control Group Design". Rancangan penelitian dapat mengikuti pola tabel 02 . 
Tabel 02. Rancangan Penelitian

\begin{tabular}{ccc}
\hline Kelas & Treatment & Post-test \\
\hline Eksperimen & $\mathrm{X}$ & $\mathrm{Q}_{1}$ \\
\hline Kontrol & - & $\mathrm{Q}_{2}$ \\
\hline
\end{tabular}

Keterangan:

(Dimodifikasi dari Sugiyono, 2011:79)

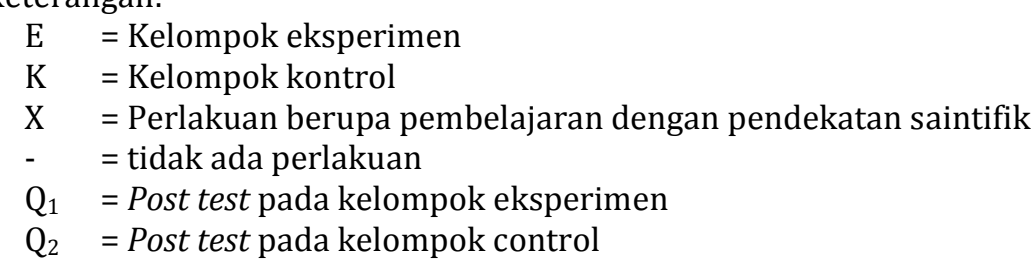

Populasi dalam penelitian ini adalah seluruh siswa kelas IV SD Gugus IV Kecamatan Tejakula Kabupaten Buleleng yang berjumlah 9 sekolah dasar.

Tabel 03 Populasi Penelitian

\begin{tabular}{llcc}
\hline No. & Sekolah & Kelas & Jumlah Siswa \\
\hline 1 & SD N 1 Bondalem & IV & 34 \\
2 & SD N 2 Bondalem & IV & 11 \\
3 & SD N 3 Bondalem & IV & 23 \\
4 & SD N 4 Bondalem & IV & 20 \\
5 & SD N 5 Bondalem & IV & 22 \\
6 & SD N 6 Bondalem & IV & 28 \\
7 & SD N 7 Bondalem & IV & 18 \\
8 & SD N 8 Bondalem & IV & 14 \\
9 & SD N 9 Bondalem & IV & 25 \\
\hline
\end{tabular}

Pada penelitian ini, teknik pemilihan sampel kelompok eksperimen dan kelompok kontrol adalah dengan kesetaraan pada populasi. Setelah hasilnya setara kemudian dilakukan random pada populasi tersebut untuk menentukan dua sekolah yang dijadikan sampel penelitian. Dari hasil random, didapatkan hasil bahwa yang menjadi kelompok eksperimen adalah SD Negeri 3 Bondalem dan kelompok kontrol adalah SD Negeri 5 Bondalem. Nantinya kelompok eksperimen diberlakukan pembelajaran dengan pendekatan saintifik berbantuan talking stick sedangkan kelompok kontrol diberlakukan pembelajaran dengan pendekatan konvensional.

Penelitian ini melibatkan dua variabel, yaitu variabel bebas dan variabel terikat. Dalam penelitian ini variabel bebasnya adalah pendekatan saintifik, sedangkan variabel terikatnya adalah keterampilan membaca. Metode pengumpulan data yang digunakan dalam penelitian ini adalah metode tes. Data yang diperlukan adalah data tentang keterampilan membaca pemahaman siswa kelompok eksperimen dan siswa kelompok kontrol setelah diberikan perlakuan yang berbeda dalam pembelajaran. Instrumen yang digunakan untuk memperoleh data tentang keterampilan membaca pemahaman siswa dalam penelitian ini berupa tes. Tes yang digunakan dalam penelitian ini adalah tes pilihan ganda (objektif) yang berjumlah 25 soal. Tiap soal berisi empat option jawaban yang dapat dipilih oleh siswa. Bila jawaban bena mendapatkan skor 1 dan jika jawaban salah maka mendapatkan skor 0 . Skor tiap soal kemudian dijumlahkan dan merupakan skor variabel keterampilan membaca pemahaman siswa. Instrumen tersebut sebelumnya diuji coba terlebih dahulu agar diketahui kelayakannya sebagai instrumen penelitian yang baik. Hasil uji coba menunjukkan bahwa instrumen penelitian tersebut telah layak digunakan.

Teknik penyajian data hasil penghitungan mean, median dan modus disajikan ke dalam grafik poligon. Dalam penelitian ini diuji sebuah hipotesis yang dilakukan dengan menggunakan uji-t sampel independent (tidak berkorelasi) dengan rumus polled varians. Sebelum melakukan hipotesis, terlebih dahulu dilakukan uji prasyarat, yang terdiri dari uji normalitas dan uji homogenitas. Hipotesis dalam peneltian ini yaitu terdapat perbedaan yang signifikan keterampilan membaca pemahaman antara siswa 
yang mengikuti pembelajaran dengan pendekatan saintifik berbantuan talking stick dan siswa yang mengikuti pembelajaran dengan pendekatan konvensional pada siswa kelas IV di SD Gugus IV Kecamatan Tejakula Tahun Pelajaran 2018/2019.

\section{Hasil Dan Pembahasan}

Data yang diperoleh dalam penelitian ini merupakan hasil dari penerapan pendekatan saintifik berbantuan talking stick yang dilakukan terhadap kelompok eksperimen dan pendekatan konvensional yang dilakukan di kelompok kontrol. Pada akhir penelitian, masing-masing kelas diberikan post-test dalam bentuk tes keterampilan membaca pemahaman. Rekapitulasi penghitungan data hasil penelitian tentang keterampilan membaca pemahaman siswa kelompok eksperimen dan kelompok kontrol dapat dilihat pada Tabel 04 berikut.

Tabel 04 Rekapitulasi Keterampilan Membaca.

\begin{tabular}{lcc}
\hline \multirow{2}{*}{ Data Statistik } & \multicolumn{2}{c}{ Keterampilan Membaca } \\
\cline { 2 - 3 } & Kelompok Eksperimen & Kelompok Kontrol \\
\hline Mean & 14,43 & 11,42 \\
Median & 14,55 & 11,40 \\
Modus & 14,62 & 11,38 \\
Varians & 4,89 & 2,72 \\
Standar Deviasi & 2,21 & 7,43 \\
Skor Minimal & 8 & 7 \\
Skor Maksimal & 19 & 18 \\
Rentangan & 11 & 11 \\
\hline
\end{tabular}

Dari Tabel 4 di atas dapat dilihat pemaparan tentang mean, median, modus, varians, dan standar deviasi data keterampilan membaca pemahaman antara kelompok siswa kelompok eksperimen dan kelompok siswa kelompok kontrol. Kemudian data hasil post-test hasil belajar keterampilan membaca pemahaman kelompok eksperimen disajikan ke dalam bentuk grafik poligon seperti pada gambar 01 berikut ini.

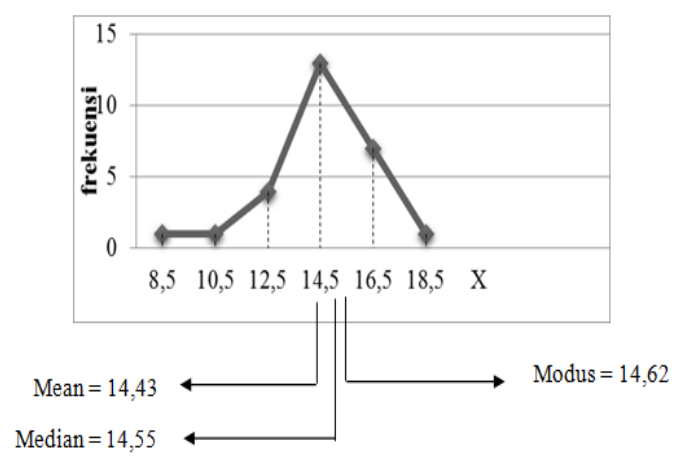

Gambar 01. Grafik Poligon Data Keterampilan Membaca Pemahaman Kelompok Eksperimen.

Gambar 01 menunjukkan bahwa modus lebih besar dari median dan median lebih besar dar mean Mo $>M d>M(14,62>14,55>14,43)$. Dengan demikian, polygon di atas menggambarkan kurva juling negatif yang berarti sebagian besar skor cenderung tinggi. Untuk mengetahui kualitas dari variabel post test keterampilan membaca pemehaman siswa skor rata-rata post test dikonversikan menggunakan kriteria rata-rata ideal (Mi) dan standar deviasi ideal (SDi). Berdasarkan hasil konversi, diperoleh bahwa skor rata-rata keterampilan membaca pemahaman siswa kelompok eksperimen dengan $M=14,43$ tergolong kriteria Tinggi.

Nilai mean, median dan modus dapat disajikan dalam bentuk kurva polygon seperti Gambar 02 . Tujuannya untuk menafsirkan sebaran data keterampilan membaca pemehaman pada kelompok kontrol. Hubungan antara mean, median, dan modus dapat digunakan untuk menentukan kemeringan kurva polygon distribusi frekuensi. 


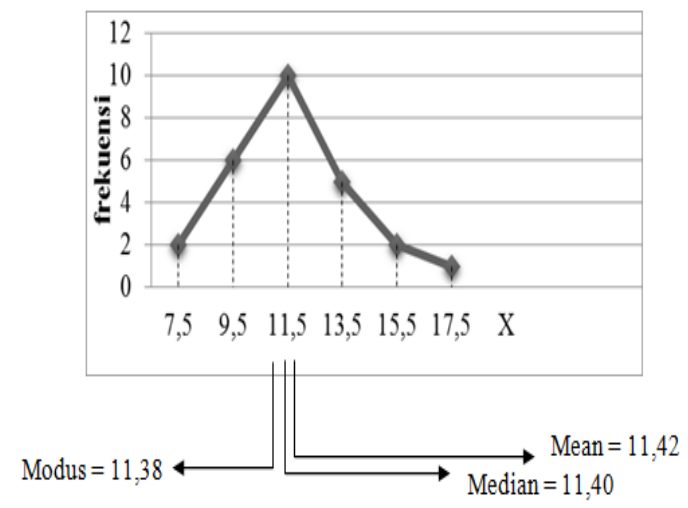

Gambar 02. Grafik Poligon Data Keterampilan Membaca Pemahaman Kelompok Kontrol.

Gambar 02 menunjukkan bahwa mean lebih besar dari median dan modus lebih besar dari modus $\mathrm{M}>\mathrm{Md}>\mathrm{Mo}(11,42>11,40>11,38)$. Dengan demikian, polygon di atas menggambarkan kurva juling positif yang berarti sebagian besar skor cenderung rendah. Untuk mengetahui kualitas dari variabel post test keterampilan membaca pemahaman siswa skor rata-rata post test dikonversikan menggunakan kriteria rata-rata ideal (Mi) dan standar deviasi ideal (SDi). Berdasarkan hasil konversi, diperoleh bahwa skor rata-rata keterampilan membaca pemahaman siswa kelompok kontrol dengan $\mathrm{M}=11,42$ tergolong kriteria Sedang.

Sebelum uji hipotesis terlebih dahulu dilakukan uji prasyarat analisis yang terdiri dari uji normalitas sebaran data dan uji homogenitas varians. Berikut diuraikan mengenai hasil uji normalitas sebaran data dan uji homogenitas varians skor keterampilan membaca pemahaman.

Uji normalitas dilakukan untuk menyelidiki suatu distribusi empirik mengikuti ciri-ciri distribusi normal atau untuk menyelidiki $f_{o}$ (frekuensi observasi) dari gejala yang diselidiki tidak menyimpang secara signifikan dari $\mathrm{f}_{\mathrm{h}}$ (frekuensi harapan) dalam distribusi normal Uji normalitas data dilakukan terhadap data post-test siswa pada keterampilan membaca kelompok eksperimen dan kelompok kontrol. Berdasarkan analisis data yang dilakukan, dapat disajikan hasil uji normalitas sebaran data post-test siswa pada keterampilan membaca kelompok eksperimen dan kelompok kontrol pada Tabel 05.

Tabel 05. Rangkuman Hasil Uji Normalitas Distribusi Post-Test Belajar siswa pada keterampilan membaca

\begin{tabular}{llccc}
\hline $\mathbf{N}$ & Kelompok Data Hasil Belajar & $\chi^{2}$ & $\begin{array}{c}\text { Nilai Kritis dengan Taraf } \\
\text { Signifikansi 5 }\end{array}$ & Status \\
$\mathbf{0}$ & & 7,08 & 11,07 & Normal \\
\hline $\mathbf{1}$ & Post-test Eksperimen & 9,02 & 11,07 & Normal \\
\hline $\mathbf{2}$ & Post-test Kontrol & & & \\
\hline
\end{tabular}

Kriteria pengujian, jika $\chi^{2}{ }_{h i t}<\chi_{\text {tab }}^{2}$ dengan taraf signifikasi $5 \%$ (dk = jumlah baris dikurangi 1), maka data berdistribusi normal. Sedangkan, jika $\chi_{h i t}^{2} \geq \chi_{\text {tab }}^{2}$ maka data tidak berdistribusi normal. Berdasarkan hasil perhitungan dengan menggunakan rumus chi-square, hasil post-test kelompok eksperimen pada taraf signifikansi $5 \%$ dengan $\mathrm{dk}=$ jumlah baris-1=6-1=5, didapatkan harga chi-square tabel sebesar 11,07 dan chi-square hitung 7,08 sehingga dapat disimpulkan bahwa $\chi_{\text {hitung }}^{2}(7,08)<\chi_{\text {tabel }}^{2}(11,07)$. Karena harga chi-square hasil penelitian lebih kecil daripada chi-square tabel maka dapat disimpulkan bahwa data hasil penelitian tersebut berdistribusi normal. Sedangkan, hasil post-test kelompok kontrol pada taraf signifikansi 5\% dengan $\mathrm{dk}=$ jumlah baris-1=6-1= 5, didapatkan harga chi-square tabel sebesar 11,07 dan chi-square hitung 9,02 sehingga dapat disimpulkan bahwa $\chi^{2}{ }_{\text {hitung }}(9,02)<\chi_{\text {tabel }}^{2}(11,07)$. Karena harga chi-square hasil penelitian lebih kecil daripada chisquare tabel maka dapat disimpulkan bahwa data hasil penelitian tersebut berdistribusi normal.

Uji homogenitas dilakukan terhadap varians pasangan antara kelompok eksperimen dan kelompok

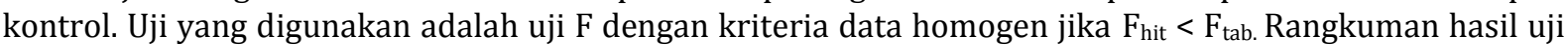
homogenitas varians antara kelompok eksperimen dan kelompok kontrol disajikan pada Tabel 06. 
Tabel 06 Rangkuman Hasil Uji Homogenitas Varians antara Kelompok Eksperimen dan Kelompok Kontrol

\begin{tabular}{lccc}
\hline \multicolumn{1}{c}{ Sumber Data } & $\mathbf{F}_{\text {hit }}$ & $\begin{array}{c}\mathbf{F}_{\text {tab }} \text { dengan Taraf } \\
\text { Signifikansi 5\% }\end{array}$ & Status \\
\hline $\begin{array}{l}\text { Post-test Kelompok } \\
\begin{array}{l}\text { Eksperimen dan Kelompok } \\
\text { Kontrol }\end{array}\end{array}$ & 1,51 & 2,09 & Homogen \\
\hline
\end{tabular}

Berdasarkan tabel di atas, diketahui $\mathrm{F}_{\text {hit }}$ hasil post-test kelompok eksperimen dan kelompok kontrol adalah 1,51. Sedangkan $F_{\text {tab }}$ dengan $d b_{\text {pembilang }}=23, d_{\text {penyebut }}=22$, dan taraf signifikansi $5 \%$ adalah 2,09 . Hal ini berarti, varians data hasil post-test kelompok eksperimen dan kelompok kontrol adalah homogen.

Berdasarkan uji prasyarat analisis data, diperoleh bahwa data hasil post-test kelompok eksperimen dan kelompok kontrol adalah normal dan homogen. Setelah diperoleh hasil dari uji prasyarat analisis data, dilanjutkan dengan pengujian hipotesis penelitian $\left(\mathrm{H}_{1}\right)$ dan hipotesis nol $\left(\mathrm{H}_{0}\right)$. Pengujian hipotesis tersebut dilakukan dengan menggunakan uji-t sampel independent (tidak berkorelasi) dengan rumus polled varians dengan kriteria $\mathrm{H}_{0}$ tolak jika $\mathrm{t}_{\text {hit }}>\mathrm{t}_{\mathrm{tab}}$ dan $\mathrm{H}$ terima jika $\mathrm{t}_{\text {hit }}<\mathrm{t}_{\text {tab. Rangkuman hasil }}$ perhitungan uji-t antar kelompok eksperimen dan kelompok kontrol disajikan pada Tabel 07.

Tabel 07 Rangkuman Hasil Perhitungan Uji-t

\begin{tabular}{clccccc}
\hline Data & \multicolumn{1}{c}{ Kelompok } & $\mathbf{N}$ & $\bar{X}$ & $\mathbf{s}^{\mathbf{2}}$ & $\mathbf{t}_{\text {hit }}$ & $\mathbf{t}_{\text {tab }}$ (t.s. 5\%) \\
\hline $\begin{array}{c}\text { Post- } \\
\text { test }\end{array}$ & Eksperimen & 23 & 14,43 & 4,89 & 5,68 & 2,007 \\
& Kontrol & 22 & 11,42 & 7,43 & & \\
\hline
\end{tabular}

Berdasarkan hasil perhitungan uji-t di atas, diperoleh $t_{\text {hit }}$ adalah 5,68 Sedangkan $t_{\text {tab }}$ dengan dk = $23+22-2=43$ dan taraf signifikansi $5 \%$ adalah 2,007. Hal ini berarti, $t_{\text {hit }}$ lebih besar dari $t_{\text {tab }}\left(t_{\text {hit }}>t_{t a b}\right)$, sehingga $\mathrm{H}_{0}$ ditolak dan $\mathrm{H}_{1}$ diterima. Jadi terdapat perbedaan keterampilan membaca pemahaman antara kelompok siswa yang dibelajarkan dengan pendekatan saintifik berbantuan talking stick dan kelompok siswa yang dibelajarkan dengan pendekatan konvensional pada siswa kelas IV SD di Gugus IV Kecamatan Tejakuula, Kabupaten Buleleng tahun pelajaran 2018/2019.

Setelah dilakukan analisis data, diketahui bahwa terdapat perbedaan keterampilan membaca antara kelompok siswa yang dibelajarkan dengan pendekatan saintifik berbantuan talking stick dan kelompok siswa yang dibelajarkan dengan pendekatan konvensional. Hal ini, Berdasarkan hasil perhitungan $u j i-t$ di atas, diperoleh $t_{\text {hit }}$ adalah 5,68 Sedangkan $t_{\text {tab }}$ dengan $\mathrm{dk}=23+22-2=43$ dan taraf signifikansi 5\% adalah 2,007. Hal ini berarti, $t_{\text {hit }}$ lebih besar dari $t_{\text {tab }}\left(t_{h i t}>t_{t a b}\right)$, sehingga $\mathrm{H}_{0}$ ditolak dan $\mathrm{H}_{1}$ diterima. Dengan demikian, terdapat perbedaan yang signifikan keterampilan membaca pemahaman antara siswa yang mengikuti pembelajaran dengan pendekatan saintifik dan siswa yang mengikuti pembelajaran dengan pendekatan konvensional pada siswa kelas IV di Gugus IV Kecamatan Tejakula tahun pelajaran 2018/2019.

Kemudian berdasarkan rata-rata skor keterampilan membaca pemahaman siswa yang mengikuti pendekatan saintifik berbantuan talking stick adalah 14,43 dan rata-rata skor keterampilan membaca pemahaman siswa yang mengikuti pendekatan konvensional adalah 11,42. Hal ini menunjukkan bahwa keterampilan membaca pemehaman kelompok siswa yang dibelajarkan dengan pendekatan saintifik berbantuan talking stick lebih tinggi dibandingkan dengan kelompok siswa yang dibelajarkan dengan pendekatan konvensional.

Adapun teori-teori yang digunakan digunakan sebagai pijakan melakukan penelitian meliputi Pendekatan Saintifik, Keterampilan Membaca Pemahaman, Talking Stick. Hal ini didukung oleh pendapat Musfigon dan Nurdiyansyah (2015:57) yang menyatakan, "penerapan pendekatan saintifik dalam pembelajaran di sekolah bertujuan membiasakan peserta didik berfikir, bersikap serta berkarya dengan menggunakan kaidah dan langkah ilmiah". Pembelajaran dengan pendekatan saintifik adalah proses pembelajaran yang dirancang sedemikian rupa agar peserta didik secara aktif mengkonstruksi konsep melalui tahap mengamati, menanya, menalar, mengasosiasikan, mengkomunikasikan. Adapun kelebihan dari pendekatan saintifik yaitu pembelajaran lebih terpusat pada siswa sehingga siswa menjadi lebih akatif dan kreatif dalam pembelajaran. Dari kelima tahap-tahap saintifik tersebut sesuai diterapkan pada pembelajaran membaca dari mencari ide, mengolah ide, sampai menyampaikan ide tersebut. Hal ini yang akan membuat siswa memiliki kemampuan belajar yang baik. 
Kelompok siswa yang dibelajarkan menggunakan pendekatan saintifik berbantuan talking stick t mampu berpikir kreatif dan aktif. Pembelajaran dengan model ini, dimulai dari membaca suatu materi pembelajaran kepada siswa agar mampu menggali informasi tentang materi pembelajaran tersebut melalui pendekatan ilmiah oleh siswa sehingga, siswa akan aktif dan terlibat langsung dalam menemukan fakta dan pengetahuannya sendiri. Dengan disajikannya materi pembelajaran siswa akan berusaha secara aktif menggali informasi secara rinci tentang materi pembelajaran tersebut melalui pengetahuan yang sudah ia miliki sebelumnya, dan kemudian mengaitkannya dengan pengetahuan yang baru yang ia temukan.

Berbeda halnya dengan kelas yang dibelajarkan secara konvensional. Pembelajaran secara konvensional yang dilakukan, guru cenderung langsung sebagai sumber informasi bagi siswa dan siswa cenderung pasif dalam kegiatan pembelajaran. Siswa menjadi pasif karena komunikasi yang terjalin hanya komunikasi satu arah yaitu antara guru dengan siswa. Pernyataan tersebut sependapat dengan Dwipayanti, (2013) yang menyatakan bahwa, "pembelajaran konvensional adalah proses pembelajaran yang masih memberikan dominasi guru dan tidak memberikan akses bagi siswa untuk berkembang secara mandiri melalui penemuan dan proses berpikirnya".

Dengan demikian, dapat disimpulkan bahwa pendekatan saintifik berbantuan talking stick berpengaruh positif terhadap keterampilan membaca siswa kelas IV SD Negeri 3 Bondalem Kecamatan Tejakula Kabupaten Buleleng Tahun Pelajaran 2018/2019. Temuan hasil penelitian di atas sesuai dengan temuan sebelumnya. Temuan penelitian tersebut antara lain sebagai berikut.

Wahyu (2015) menyatakan bahwa terdapat perbedaan keterampilan membaca antara siswa yang dibelajarkan dengan pendekatan saintifik berbantuan media gambar dengan siswa yang tidak dibelajarkan menggunakan pendekatan saintifik berbantuan media gambar terhadap keterampilan membaca siswa kelas IV SD Negeri 3 Panji Kabupaten Buleleng.Berdasarkan analisis data yang sudah dilakukan terhadap hasil post-test ditemukan bahwa kelompok siswa yang dibelajarkan dengan model pembelajaran Pendekatan Saintifik berbantuan Talking Stick memperoleh skor rata-rata 14,43 lebih tinggi dibandingkan dengan kelompok siswa yang dibelajarkan secara konvensional, hanya memperoleh skor rata-rata yaitu 11,42 berdasarkan analisis Uji-t mengeni analisi uji hipotesis penelitian diperoleh $t_{\text {hitung }}$ 5,68 lebih besar dibandingkan dengan $t_{\text {tabel }}$ yaitu 2.007. Berdasarkan hal tersebut maka dapat diartikan terdapat pengaruh yang signifikan pengaruh pendekatan saintifik berbantuan talking stick terhadap keterampilan membaca siswa kelas IV SD Gugus IV Kecamatan Tejakula.

\section{Simpulan Dan Saran}

Berdasarkan hasil uji hipotesis dan pembahasan, maka simpulan dari penelitian ini adalah terdapat perbedaan yang signifikan hasil belajar keterampilan membaca pemahaman antara kelompok siswa yang dibelajarkan dengan pendekatan saintifik berbantuan talking stick dan kelompok siswa yang belajar dengan pendekatan konvensional. Berdasarkan rumusan masalah dan hasil penelitian, maka simpulan dalam penelitian ini adalah dari hasil analisis, diperoleh $t_{\text {hit }}$ sebesar 5,68 lebih dari $t_{\text {tab }}$ sebesar 2,007 yang diuji pada taraf signifikansi 5\% dengan derajat kebebasan 43. Hal ini berarti terdapat perbedaan yang signifikan keterampilan membaca siswa kelompok siswa yang mengikuti pembelajaran menggunakan pendekatan saintifik berbantuan talking stick dan kelompok siswa yang mengikuti pembelajaran secara konvensional. Berdasarkan hal tersebut diketahui bahwa pendekatan saintifik berbantuan talking stick berpengaruh terhadap keterampilan membaca siswa kelas IV di Gugus IV Kecamatan Tejakula Kabupaten Buleleng Tahun Pelajaran 2018/2019.

Saran yang dapat disampaikan berdasarkan penelitian yang telah dilakukan adalah sebagai berikut. Pertama, para siswa di SD disarankan agar mampu belajar mandiri, mengeksplorasi diri sendiri, mampu berpikir kreatif dan agar meningkatkan keaktifannya lagi dalam pembelajaran, sehingga nantinya dapat meningkatkan hasil belajar dan lebih banyak menemukan dan mendapatkan pengetahuan-pengetahuan baru. Kedua, guru di SD agar lebih berinovasi dalam pembelajaran baik di kelas maupun lingkungan lainnya dengan cara memilih dan menerapkan suatu pendekatan yang dirasa tepat sesuai dengan karakteristik dan kebutuhan siswa. Ketiga, peneliti lain yang berminat untuk melakukan penelitian lebih lanjut tentang pendekatan saintifik berbantuan talking stick, agar menyesuaikan dengan permasalahan di lapangan dan tetap memperhatikan kendala-kendala yang dialami dalam penelitian ini sebagai bahan pertimbangan nantinya sehingga dapat dilakukan perbaikan dan penyempurnaan pada penelitian yang dilakukan. 


\section{Daftar Rujukan}

Agung, A. A. Gede. 2014. Metodologi Penelitian Pendidikan. Malang: Aditya Media.

Agung, A. A. Gede. 2016. Statistika Dasar untuk Pendidikan. Yogyakarta: CV Budi Utama

Alek dan Achmad. 2011. Bahasa Indonesia Untuk Perguruan Tinggi. Jakarta: Prenada Media Grup.

Candiasa, I Made. 2010a. Statistika Univariat dan Bivariat Disertai Aplikasi SPSS. Singaraja: Undiksha

Daryanto, 2014. Pendekatan Pembelajaran Saintifik Kurikulum 2013: Yogyakarta: Gava media.

Dibia, I Ketut, Dkk. 2007. Pendidikan Bahasa Indonesia 2. Singaraja: Undiksha.

Phalguna, Komang Wahyu. 2015. Pengaruh Pendekata Saintifik Berbantuan Media Gambar Terhadap Hasil Belajar Keterampilan Membaca Pemahaman Siswa SD Kelas V. E-jurnal Universitas Pendidikan Ganesha Mimbar PGSD: MIMBAR GSD VOL. NO 1 Tahun 2015.

Sugiyono. 2012. Metode Penelitian Pendidikan (Pendekatan Kuantitatif, Kualitatif dan R\&D. Bandung: Alfabeta.

Susanto, Ahmad. 2013. Teori Belajar dan Pembelajaran di Sekolah Dasar. Jakarta: Kencana Prenada Media Group.

Sani, Ridwan Abdullah. 2014. Penelajaran Saintifik Untuk Implementasi Kurikulum 2013. Jakarta: Bumi Aksara.

Suandi, I Nengah dkk. 2018. Keterampilan Berbahasa Indonesia BerorientaIntegrasi Nasional dan Hasmoni Sosial. Depok: Rajawali Pers 